\title{
Effects of Major and Minor Elements, Lime, and Soil Amendments on the Yield and Ascorbic Acid Content of Acerola (Malpighia punicifolia L.)
}

\author{
P. Landrau, Jr., and E. Hernández Medina ${ }^{1}$
}

INTRODUCTION

Fruits vary considerably in their ascorbic acid content. Of the edible ones, the acerola, or West Indian cherry, stands exceptionally high in this respect. Munsell and Quiñones $(11,13)^{2}$ reported values for a number of tropical fruits among which the acerola ranked several times higher than the next best. Asenjo and Freire de Guzmán (2) reported values for acerola that ranged from 1 to $3 \mathrm{gm}$. of ascorbic acid per $100 \mathrm{gm}$. of edible matter. Mustard (12) obtained values as high as $4.468 \mathrm{gm}$. per $100 \mathrm{gm}$. of edible pulp for green fruit. Moscoso (10), and Aróstegui and Pennock (1) reported on the ascorbic acid content of several clones of acerola grown on a Rio Piedras clay soil. The investigators last named reported values that ranged from 1.325 to $3.250 \mathrm{gm}$. of ascorbic acid per $100 \mathrm{ml}$. of freshly extracted juice.

The acerola plant is a small bushy tree that can be grown satisfactorily under a wide range of soil and climatic conditions. Much interest has been aroused lately concerning the cultivation and industrial possibilities of the fruit. Moscoso (10), and Aróstegui and Pennock (1) have reported on the history and culture of this tropical tree.

The fruit of the acerola varies in size from $1 / 2$ to approximately 1 inch in diameter, depending on the clone or variety; in color it varies from lightgreen when unripe to deep bright red when fully ripe. The tree bears from early spring until early winter, and the fruits take only about 22 days to develop completely from the flower stage.

During recent years great interest has been aroused in the canning industry regarding the use of natural vitamin $C$ for enriching other juices and canned fruit products. In view of the industrial potentialities that the acerola offers as such a source it was considered important to determine its fertilizer requirements.

The results of a fertilizer experiment with acerola at Rio Piedras are reported in this paper. The research included both major- and minor-element fertilizers, lime, and soil amendments applied to the soil in different quan-

\footnotetext{
1 Former Associate Agronomist and Associate Horticulturist, respectively, Agricultural Experiment Station, University of Puerto Rico, Río Piedras, P.R.

2 Italic numbers in parentheses refer to Literature Cited, pp. 32-3.
} 
tities, in order to study their effects on the yield and ascorbic acid content of the acerola. Minor elements were also applied via the foliage.

\section{EXPERIMENTAL PROCEDURE}

The investigation began at the Station grounds at Río Piedras on September 9, 1953. The acerola trees were grown in pots on a Sabana Seca sandy clay soil ( $\mathrm{pH} 4.5$ ) obtained from a field where acerolas have been cultivated on a commercial scale. This is a grayish-brown soil probably derived from old marine deposits and mixed materials washed from the uplands. It occurs in the northern coastal plains and inland valleys not more than 5 miles from the seashore. Its topography varies from nearly level to undulating, with an annual rainfall ranging from 60 to 75 inches (15).

The soil for the experiment was taken from the top 8 inches. It was airdried in the greenhouse and passed through a $1 / 4$-inch screen. Fifty-fivegallon drums were cut in halves, and these were ebonol-painted and filled with the screened soil to about 1 inch from the top. The area of each drum corresponded to $1 / 16,525$ th of an acre in surface, or approximately 2.64 square feet of soil surface. Lime was applied in all treatments, except the control, to raise the original soil $\mathrm{pH}$ of 4.5 to 6.5 , following lime-requirement tests (14). The lime was carefully mixed with the soil before filling the drums. Perforations were made in the bottom of each drum to prevent water-logging. The drums were placed on wooden platforms to prevent penetration of the roots through the holes into the bottom soil.

For nematode control the soil was fumigated with DD (dichloropropanedichloropropene) at the rate of $3 \mathrm{cc}$. of the fumigant per square foot. Soil insects and worms were controlled with Aldrin at the rate of 2 pounds of the technical material per acre. Aphids were controlled with Isotox (gamma isomer of benzene hexachloride from Lindane) at the rate of 1 pint per 100 gallons of water, while scale insects were controlled with Vaphopos (parathion) at the rate of 1 pound of the 15-percent wettable powder per 100 gallons of water.

The experiment consisted of 16 fertilizer treatments, each replicated three times, and was planted following a rectangular lattice design. The treatments used in the work are shown in table 1.

In all treatments the fertilizers, lime, and organic compounds were mixed with the soil, except for Nos. 12 and 13, in which the minor-element mixtures were sprayed on the trees. The two organic compounds tested were filter-press cake and Hyper-Humus. Filter-press cake is an organic byproduct of the sugar mills. On a dry-weight basis it has an average composition of 2.19 percent of nitrogen $(\mathrm{N}), 2.77$ of phosphorus $\left(\mathrm{P}_{2} \mathrm{O}_{5}\right), 0.44$ of potassium $\left(\mathrm{K}_{2} \mathrm{O}\right), 3.05$ of calcium $(\mathrm{CaO}), 39.5$ of organic matter, and approximately $0.49,1.17,1.05$, and 0.01 percent of magnesium ( $\mathrm{MgO})$, manganese 
$\left(\mathrm{MnO}_{2}\right)$, iron $\left(\mathrm{Fe}_{2} \mathrm{O}_{3}\right)$ and boron $\left(\mathrm{B}_{2} \mathrm{O}_{3}\right)$, respectively. The analyses reported above for the major elements are averages from 43 samples. The values for the microelements are averages of 2 to 6 samples.

Hyper-Humus is a product from the decomposition of sedge peat containing from 80 to 90 percent of organic matter, and is merely used to build up the organic-matter level of the topsoil. It has a very low nutrient value. The "fritted trace elements" used is a type of slowly soluble glass containing

TABLE 1.-Major-and minor-element treatments (in pounds per acre) used in studying the effects of fertilizer applications on the yield and ascorbic acid content of acerola fruit

\begin{tabular}{|c|c|c|c|c|c|}
\hline \multirow{2}{*}{$\begin{array}{c}\text { Treat- } \\
\text { ment } \\
\text { No. }\end{array}$} & \multicolumn{3}{|c|}{$\underset{\text { per acre }}{\text { Major elements used }}$} & \multicolumn{2}{|c|}{ Minor element or soil amendment } \\
\hline & $\mathbf{N}$ & $\mathrm{P}_{2} \mathrm{O}_{3}$ & $\mathrm{~K}_{2} \mathrm{O}$ & Material & Quantity \\
\hline & $L b$. & $L b$. & $L b$. & & \\
\hline 1 & 0 & 200 & 200 & & \\
\hline 2 & 100 & 200 & 200 & & \\
\hline 3 & 200 & 0 & 200 & & \\
\hline 4 & 200 & 100 & 200 & & \\
\hline 5 & 200 & 200 & 0 & & \\
\hline 6 & 200 & 200 & 100 & & \\
\hline 7 & 200 & 200 & 200 & & \\
\hline 8 & 200 & 200 & 200 & Hyper-Humus & 20,000 \\
\hline 9 & 200 & 200 & 200 & F.T.E. (fritted trace elements) & 200 \\
\hline 10 & 200 & 200 & 200 & EDTA Fe (chelated iron) & 100 \\
\hline 11 & 200 & 200 & 200 & ES-MIN-EL (minor-element mixture) & 100 \\
\hline 12 & 200 & 200 & 200 & do. & 4 lb./100/gal. water \\
\hline 13 & 200 & 200 & 200 & Nutri-Leaf (soluble minor elements) & $6 \mathrm{lb} . / 100 /$ gal. water \\
\hline 14 & 200 & 200 & 200 & Filter-press cake $+1 / 2$ treatment 7 & 40,000 \\
\hline 15 & 200 & 200 & 200 & $\begin{array}{l}\text { Mineral-Mixture (minor-element mix- } \\
\text { ture) }\end{array}$ & 100 \\
\hline 16 & 200 & 200 & 200 & Control, NPK only, no lime & \\
\hline
\end{tabular}

1 Relatively insoluble.

zinc, iron, copper, manganese, boron, and molybdenum. It is sold commercially as FerroFTE. The EDTAFe, or chelated iron, is a sodium ferric ethylene-diamine tetra-acetate (12-percent $\mathrm{Fe}$ ) sold commercially as Sequestrene NaFe. ES-MIN-EL is a fertilizer mixture readily available commercially which, in addition to magnesium, contains the minor elements manganese, zinc, copper, iron, and boron. It can be used both for soil application and foliar sprays. Nutri-Leaf is a commercial soluble fertilizer which contains nitrogen, phosphorus, potassium, magnesium, and the minor elements mentioned above, except molybdenum. It can be used also for soil or foliar applications. Mineral Mixture is a commercial minor-element fertilizer 
which also contains magnesium and which is recommended for soil application only. The major fertilizer elements for each corresponding treatment were compounded from ammonium sulfate (20-percent $N$ ), superphosphate (20-percent $\mathrm{P}_{2} \mathrm{O}_{5}$ ), and potassium chloride (60-percent $\mathrm{K}_{2} \mathrm{O}$ ).

An outstanding West Indian cherry clone, B-17, was selected for this study because of its unusually high ascorbic acid content, good fruit size, and high yield of fruit per acre and of juice per fruit. The average fruit weight ranges from 9 to $12 \mathrm{gm}$. with a mean diameter of 1.25 inches. Cuttings were made approximately 10 inches in length and $1 / 4$ inch in thickness from healthy trees of the selected clone. These were placed individually in 1-gallon cans filled with a mixture of equal parts of sand and loam soil. The cans were placed in a mist house until roots and leaves developed, which took several weeks. Forty-eight rooted cuttings were selected, considering uniformity in size and general appearance. One cutting with part of the soil holding the roots in position was planted in each drum, after which each drum was duly identified according to treatment. The plants were watered as necessary. The fertilizer used per tree was split into three applications. The first application was made 2 weeks after planting, the second when the trees started to bloom in March, and the third and last in October. Fertilizer was applied in subsequent years according to treatment schedule.

The trees started to bear early in the spring and continued to do so until early winter every year. Three pickings were made each year of harvest. The fruits were harvested, counted, and the weights recorded. Sufficient fruits were taken from each tree for chemical analyses. The fruits selected were fully ripe cherries as evidenced by their red color. Care was exercised not to pick overripened fruits. The ascorbic acid was determined on the whole fruit. The sample was ground in an osterizer until a homogenous mixture was formed and this crushed material was analyzed. The ascorbic acid was determined by the Ballentine method (4). All chemical analyses were made the same day the fruits were picked.

Leaf-nutrient contents were ascertained by the following methods: Total nitrogen was determined by the A.O.A.C. Kjeldahl method (3). Phosphorus was determined by the modified Wolf procedure $(6)$. Potassium was determined using the flame photometer $(6)$.

\section{EXPERIMENTAL RESULTS}

MAJOR ELEMENTS AND LIME

\section{Yield and ascorbic acid}

Results on the influence of nitrogen, phosphorus, and potassium on acerola yields and ascorbic acid content of the fruit are presented in table 
2. Significant reductions were obtained when either nitrogen, phosphorus, or potassium was omitted from the fertilizer mixture. When 200 pounds of

TABLE 2.-Influence of nitrogen, phosphorus, and potassium on the yield and ascorbic acid content of acerolas grown on Sabana Seca sandy clay, 1954-56 ${ }^{1}$, as compared with the Mitscherlich (6) maximum in quantity and percentage

\begin{tabular}{|c|c|c|c|c|c|c|c|}
\hline \multicolumn{3}{|c|}{ Major elements used per acre? } & \multicolumn{3}{|c|}{ Mean yield of fruits per acre } & \multirow{2}{*}{$\begin{array}{l}\text { Mean yields } \\
\text { for all } \\
\text { treatments, } \\
1954-56\end{array}$} & \multirow{2}{*}{$\begin{array}{l}\text { Ascorbic acid } \\
\text { per } 100 \mathrm{gm} \text {. } \\
\text { whole fruit, } \\
\text { crop } 1955\end{array}$} \\
\hline $\mathbf{N}$ & $\mathrm{P}_{2} \mathrm{O}_{3}$ & $\mathrm{~K}_{2} \mathrm{O}$ & 1954 & 1955 & 1956 & & \\
\hline \multicolumn{8}{|c|}{ Nitrogen $(N)$} \\
\hline$L b$. & $L b$. & $L b$. & Cwt. & $C w t$. & Cwl. & Cwt. & Ifg. \\
\hline 0 & 200 & 200 & 0.89 & 15.48 & 5.41 & 7.26 & 1,428 \\
\hline 100 & 200 & 200 & 6.28 & 25.00 & 17.20 & 16.16 & 1,368 \\
\hline 200 & 200 & 200 & 19.21 & 32.74 & 22.17 & 24.71 & 1,842 \\
\hline Mitsche & $\max$ & yield & - & 65.43 & 25.80 & 235.47 & - \\
\hline $\begin{array}{r}\text { Percent } \\
\text { realiz }\end{array}$ & of th & ximum & - & 50.04 & 85.93 & 10.49 & - \\
\hline \multicolumn{8}{|c|}{ Phosphorus $\left(\mathrm{P}_{2} \mathrm{O}_{5}\right)$} \\
\hline 200 & $\mathbf{0}$ & 200 & 0.85 & 10.46 & 14.37 & 8.56 & 1,328 \\
\hline 200 & 100 & 200 & 4.73 & 22.58 & 21.93 & 16.41 & 1,477 \\
\hline 200 & 200 & 200 & 19.21 & 32.74 & 22.17 & 24.71 & 1,842 \\
\hline Mitsche & $\max$ & yield & - & 85.27 & 22.18 & - & - \\
\hline $\begin{array}{r}\text { Percent } \\
\text { realiz }\end{array}$ & the & num & 一 & 38.40 & 99.95 & - & - \\
\hline \multicolumn{8}{|c|}{ Potassium $\left(\mathrm{K}_{2} \mathrm{O}\right)$} \\
\hline 200 & 200 & 0 & 4.80 & 14.98 & 4.49 & 8.09 & 1,394 \\
\hline 200 & 200 & 100 & 8.13 & 24.15 & 20.62 & 17.63 & 1,309 \\
\hline 200 & 200 & 200 & 19.21 & 32.74 & 22.17 & 24.71 & 1,842 \\
\hline \multirow{2}{*}{\multicolumn{3}{|c|}{$\begin{array}{l}\text { Mitscherlich's maximum yield } \\
\text { Percentage of the maximum } \\
\text { realized }\end{array}$}} & - & 146.41 & 27.15 & 45.07 & - \\
\hline & & & - & 22.36 & 80.16 & 54.83 & - \\
\hline \multicolumn{3}{|c|}{$\begin{array}{l}\text { L.S.D. at the 5-percent level ... } \\
\text { L.S.D. at the 1-percent level ... }\end{array}$} & $\begin{array}{l}5.69 \\
7.66\end{array}$ & $\begin{array}{l}6.54 \\
8.81\end{array}$ & $\begin{array}{l}5.82 \\
7.83\end{array}$ & $\begin{array}{l}3.24 \\
4.17\end{array}$ & $\begin{array}{l}247 \\
333\end{array}$ \\
\hline
\end{tabular}

1 Yield calculated on the basis of 218 trees per acre.

${ }^{2}$ All treatments received $4,000 \mathrm{lb}$. of lime to raise soil $\mathrm{pH}$ to 6.5 .

each of the major fertilizer elements was used significant increases were obtained in all years. When 100 pounds was used significant increases in yield were obtained for all years except 1954, when the trees started to bear. Thus the use of 200 pounds of each major element was significantly better 
than 100 pounds for acerola production in all years. The application of the first 100 pounds of each fertilizer element did not significantly affect the ascorbic acid content of the fruit; however, the use of an additional 100

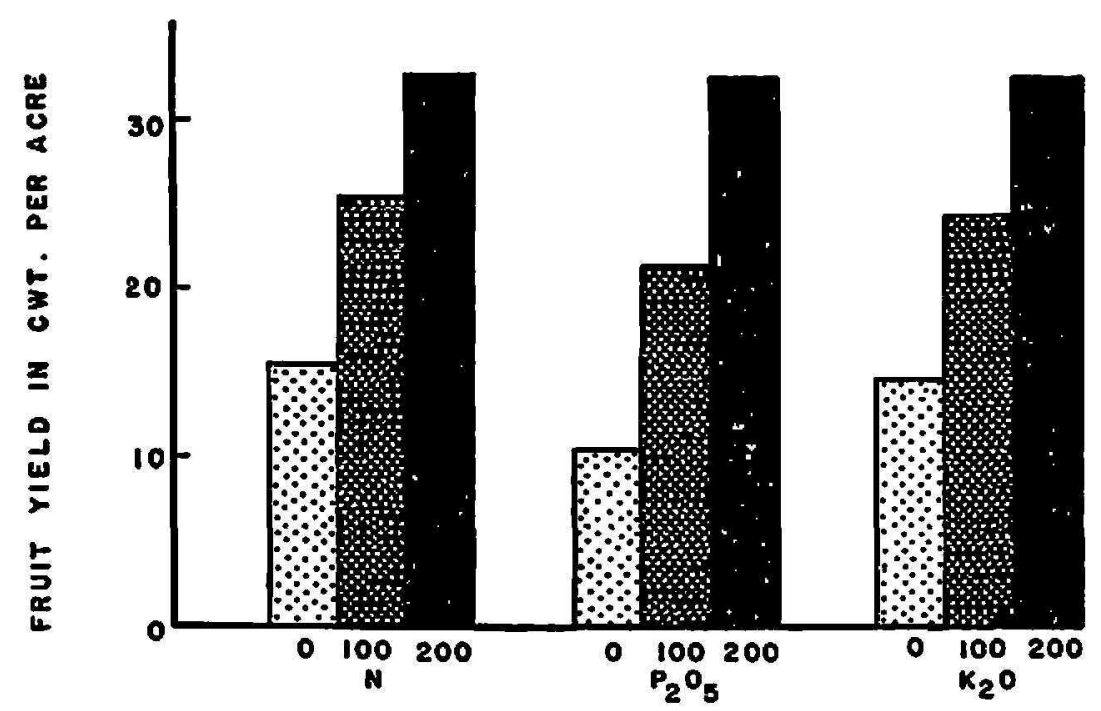

FER TILIZER APPLIED (POUNDS PER ACRE)

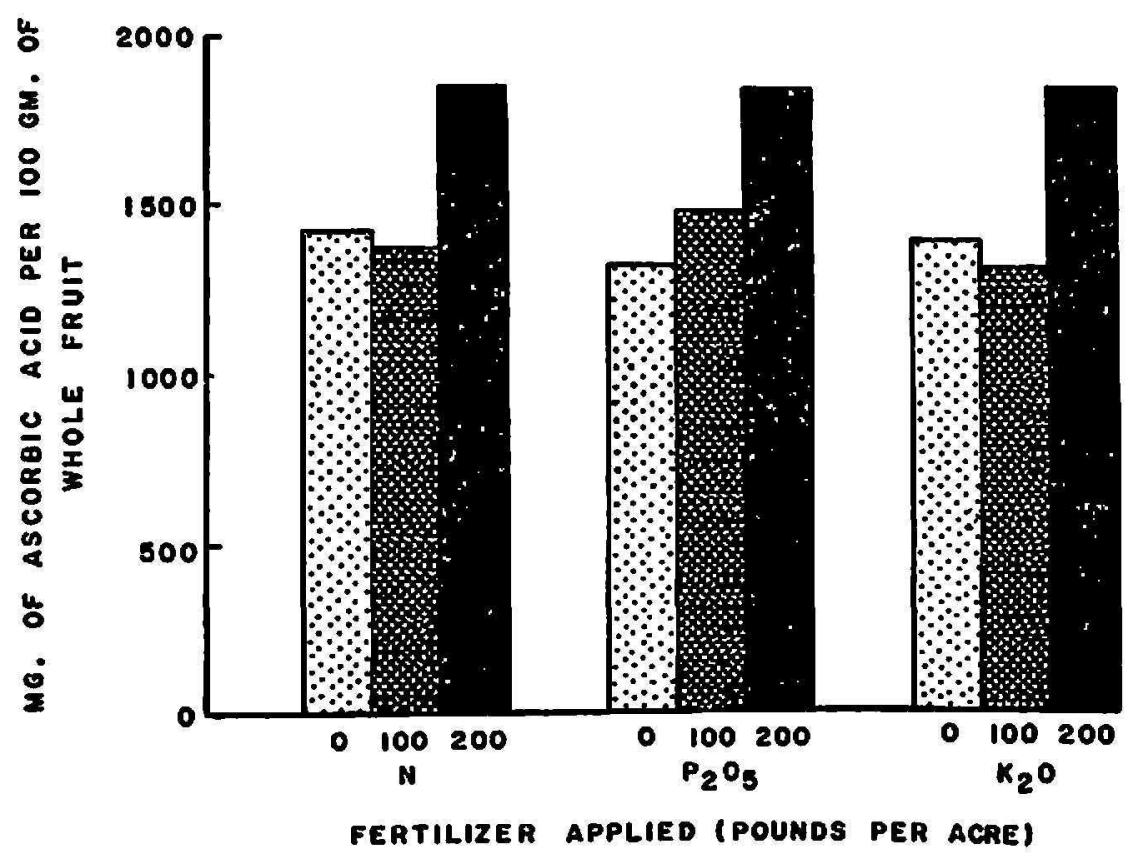

FIG. 1.-Yield and ascorbic acid content of acerola as related to applications of nitrogen, phosphor us, and potassium, when grown on Sábana Seca sandy clay, crop of 1955.

pounds of each fertilizer nutrient did increase the ascorbic acid of the fruit significantly. Figure 1 illustrates graphically the influence of rates of majorelement applications on fruit yield and ascorbic acid content of the fruit for the crop of 1955. This trend was consistent for all years.

The percentage reduction in yield for the average of three crops and the 
ascorbic acid content of the fruit in the year 1955 as affected by the omission of given elements are shown in table 3. When the maximum of any one of the major elements was used the omission of nitrogen produced the greatest reduction in yield, 70.62 percent; this was followed by the effects of lack of potassium and phosphorus, which reduced yields almost as much as did the absence of nitrogen, or 67.26 and 65.36 percent, respectively. The percentage reductions in yield in all cases were lower with the use of 100 pounds of each of the fertilizer elements, but still significant as compared to the use of 200 pounds per acre. There were significant reductions in yield of ascorbic acid when any of the major elements was omitted from

TABLE 3.-Reductions in yield and ascorbic acid content of acerolas grown on Sabana Seca sandy clay, 1954-56, attributable to the onission of major fertilizer elements and lime ${ }^{1}$

\begin{tabular}{c|c|c|c|c|c|c|c}
\hline & \multicolumn{2}{|c|}{ Percentage reduction in yield and ascorbic acid content resulting from the omission of } \\
the indicated element and lime
\end{tabular}

${ }^{1}$ Percentage reduction in yield and ascorbic acid content resulting from the omission of a given fertilizer element, using the maximum application of 200 pounds per acre of $\mathrm{N}, \mathrm{P}_{2} \mathrm{O}_{5}, \mathrm{~K}_{2} \mathrm{O}$, respectively as a base. ${ }^{*}$ Significant at the 5-percent level; ** significant at the 1-percent level.

2 For lime the basis of comparison was $4,000 \mathrm{lb}$. per acre.

${ }^{3}$ Average of 3 crops.

11955 crop.

the fertilizer mixture as compared with the maximum of each nutrient used. Table 3 further shows that the omission of lime significantly reduced yield and ascorbic acid content 50.42 and 29 percent, respectively.

Using the concept of Mitscherlich's maximum yield (5), the theoretical maximum yield was not fulfilled for any of the major elements in the crop of 1954, nor for phosphorus for the average yield of three crops. This was because the yield increments among the different rates of the nutrients concerned did not follow the law of diminishing returns. However, Mitscherlich's concept for maximum yields did work out for all major elements in the crops of 1955 and 1956.

As the data show, the percentage of the theoretical maximum yield when the maximum quantity of fertilizer nutrient was used was considerably 
higher for the crop year 1956 than for that of 1955 . Mitscherlich's concept for maximum yield could also be applied to the yield increments for the average of three crops for different rates of nutrients. However, in this experiment it was applicable only to nitrogen and potassium, and not to

TABLE 4.-Mean leaf-nutrient content of acerolas grown under different levels of nitrogen, phosphorus, and potassium on Sabana Seca sandy clay, 1956

\begin{tabular}{|c|c|c|c|c|c|c|}
\hline \multirow{2}{*}{ Treatment No. } & \multicolumn{3}{|c|}{ Major elements used per acre } & \multicolumn{3}{|c|}{$\begin{array}{l}\text { Nutrient content of acerola leaves, } \\
\text { dry-weight basis }{ }^{1}\end{array}$} \\
\hline & $\mathrm{N}$ & $\mathbf{P}_{2} \mathrm{O}_{3}$ & $\mathrm{~K}_{2} \mathrm{O}$ & $\mathrm{N}^{2}$ & $\mathrm{P}_{2} \mathrm{O}_{5^{2}}$ & $\mathrm{~K}_{2} \mathrm{O}_{2}$ \\
\hline & $L b$. & $L b$ & Lb. & Percent & Percent & Percent \\
\hline 1 & 0 & 200 & 200 & 1.40 & 1.12 & 2.05 \\
\hline 2 & 100 & 200 & 200 & 1.74 & .41 & 1.87 \\
\hline 3 & 200 & 0 & 200 & 2.01 & .13 & 1.71 \\
\hline 4 & 200 & 100 & 200 & 1.86 & .19 & 1.30 \\
\hline 5 & 200 & 200 & 0 & 3.26 & .48 & .32 \\
\hline 6 & 200 & 200 & 100 & 2.00 & .27 & .61 \\
\hline 7 & 200 & 200 & 200 & 1.85 & .28 & 1.08 \\
\hline $\begin{array}{l}\text { L.S.D. at } t \\
\text { L.S.D. at } t\end{array}$ & erc & & & $\begin{array}{r}0.31 \\
.45\end{array}$ & $\begin{array}{r}0.20 \\
.28\end{array}$ & $\begin{array}{r}0.56 \\
.79\end{array}$ \\
\hline
\end{tabular}

1 Leaf samples were taken after the last picking of the 1956 crop.

2 To compare treatments for each fertilizer element, use treatments 1,2 , and 7 for nitrogen; 3, 4, and 7 for phosphorus; and 5, 6, and 7 for potassium.

TABLE 5.-Influence of major fertilizer elements and lime on the mean weight of acerola fruits and roots grown on Sabana Seca sandy clay, 1954-56'

\begin{tabular}{|c|c|c|c|c|c|}
\hline \multirow{2}{*}{ Treatment No. } & \multicolumn{3}{|c|}{ Major elements used per acre 2} & \multirow{2}{*}{$\begin{array}{l}\text { Mean weight of } \\
\text { acerola fruit, } 1955 \\
\text { crop }\end{array}$} & \multirow{2}{*}{$\begin{array}{l}\text { Mean weight of } \\
\text { acerola roots, } 1956\end{array}$} \\
\hline & $\mathbf{N}$ & $\mathrm{P}_{2} \mathrm{O}_{6}$ & $\mathrm{~K}_{2} \mathrm{O}$ & & \\
\hline $\begin{array}{l}1 \\
2 \\
3 \\
4 \\
5 \\
6 \\
7 \\
8\end{array}$ & $\begin{array}{r}L b . \\
0 \\
100 \\
200 \\
200 \\
200 \\
200 \\
200 \\
200\end{array}$ & $\begin{array}{r}L b . \\
200 \\
200 \\
0 \\
100 \\
200 \\
200 \\
200 \\
200\end{array}$ & $\begin{array}{r}L b . \\
200 \\
200 \\
200 \\
200 \\
0 \\
100 \\
200 \\
200\end{array}$ & $\begin{array}{c}G m . \\
6.225 \\
5.522 \\
6.699 \\
5.390 \\
5.984 \\
5.691 \\
4.419\end{array}$ & $\begin{array}{r}\text { Gm. } \\
792 \\
734 \\
704 \\
630 \\
192 \\
509 \\
1,168 \\
345\end{array}$ \\
\hline $\begin{array}{l}\text { L.S.D. at th } \\
\text { L.S.D. at th }\end{array}$ & $\begin{array}{l}\text { erce: } \\
\text { erce }\end{array}$ & & & $\begin{array}{r}0.453 \\
.611\end{array}$ & $\begin{array}{l}406 \\
564\end{array}$ \\
\hline
\end{tabular}

${ }^{1}$ All treatments except No. 8 received $4,000 \mathrm{lb}$. of lime to raise soil $\mathrm{pH}$ to 6.5 .

2 To compare treatments for each fertilizer element, use treatment 1,2 , and 7 for nitrogen; 3,4 , and 7 for phosphorus; and 5, 6, and 7 for potassium. 
phosphorus. The results presented for a 3-year crop suggest that additional yield data would probably have given a better picture of the applicability of Mitscherlich's concept of maximum yield.

TABLE 6.-Mean production of acerola trees as influenced by minor-element ferlilizers, lime, and other soil amendments when grown on Sabana Seca sandy clay, 1954-56

\begin{tabular}{|c|c|c|c|c|c|c|c|c|c|}
\hline \multirow{2}{*}{$\begin{array}{l}\text { Treat- } \\
\text { ment } \\
\text { No. }\end{array}$} & \multicolumn{3}{|c|}{$\begin{array}{l}\text { Major elements } \\
\text { used per acre }\end{array}$} & \multirow{2}{*}{ Minor element or soil amendment } & \multirow{2}{*}{$\begin{array}{c}\text { Rate per } \\
\text { acre }^{2}\end{array}$} & \multicolumn{3}{|c|}{$\underset{\text { acre }^{2}}{\text { Mean yield of acela per }}$} & \multirow{2}{*}{$\begin{array}{c}\text { Mean } \\
\text { for } \\
\text { treat- } \\
\text { ments, } \\
1954-56\end{array}$} \\
\hline & $\mathbf{N}$ & $\mathrm{P}_{3} \mathrm{O}_{5}$ & $\mathrm{~K}: \mathrm{O}$ & & & 1954 & 1955 & 1956 & \\
\hline & $L b$. & $\boldsymbol{L b}$. & $L b$. & & Lb. & Cwt. & Czol. & Cwt. & $C_{w w t .}$ \\
\hline 7 & 200 & 200 & 200 & Lime only & & 19.21 & 32.74 & 22.17 & 24.71 \\
\hline 8 & 200 & 200 & 200 & Hyper-Humus & 20,000 & 5.69 & 21.30 & 12.60 & 13.20 \\
\hline 9 & 200 & 200 & 200 & $\begin{array}{l}\text { F.T.E. (fritted trace ele- } \\
\text { ments) }\end{array}$ & 200 & 3.49 & 21.63 & 18.62 & 14.58 \\
\hline 10 & 200 & 200 & 200 & EDTA Fe (chelated iron) & 100 & 6.54 & 22.82 & 15.87 & 15.08 \\
\hline 11 & 200 & 200 & 200 & $\begin{array}{l}\text { ES-MIN-EL (minor-ele- } \\
\text { ment mixture) }\end{array}$ & 100 & 11.68 & 26.88 & 20.56 & 19.71 \\
\hline 12 & 200 & 200 & 200 & do. & $4^{4}$ & 6.71 & 22.24 & 20.03 & 16.33 \\
\hline 13 & 200 & 200 & 200 & $\begin{array}{l}\text { Nutri-Leaf (soluble minor } \\
\text { elements) }\end{array}$ & $6^{4}$ & 12.82 & 34.10 & 21.89 & 22.94 \\
\hline 14 & 100 & 100 & 100 & Filter-press cake & 40,000 & 9.05 & 28.71 & 22.35 & 20.04 \\
\hline 15 & 200 & 200 & 200 & $\begin{array}{l}\text { Mineral-Mixture (minor- } \\
\text { element mixture) }\end{array}$ & 100 & 5.97 & 24.09 & 17.68 & 15.91 \\
\hline 16 & 200 & 200 & 200 & Unlimed (pH 4.5) & - & 4.67 & 20.91 & 11.16 & 12.25 \\
\hline \multicolumn{6}{|c|}{$\begin{array}{l}\text { L.S.D. at the } 5 \text {-percent level } \ldots \ldots \ldots \ldots \ldots \ldots \ldots \ldots \ldots \ldots \\
\text { L.S.D. at the } 1 \text {-percent level } \ldots \ldots \ldots \ldots \ldots \ldots \ldots \ldots \ldots \ldots\end{array}$} & $\begin{array}{l}5.69 \\
7.66\end{array}$ & $\begin{array}{l}6.54 \\
8.81\end{array}$ & $\begin{array}{l}5.82 \\
7.83\end{array}$ & $\begin{array}{l}6.08 \\
8.12\end{array}$ \\
\hline
\end{tabular}

${ }^{1}$ All treatments except No. 16 received 4,000 lb. of lime to raise soil pH to 6.5.

2 Material mixed with the soil.

3 Yields per acre of acerola calculated on the basis of 218 trees.

- Material mixed with water and sprayed on tree at the rate of 100 gal. per acre.

\section{Major elements in leaves}

The results of the quantitative analyses for nitrogen, phosphorus, and potassium of the acerola leaves taken at the last harvest are presented in table 4. Here there were definite increases in leaf nitrogen, phosphor us, and potassium with increasing applications of these nutrients. This was reflected in increased fruit yields. The highest fruit yields and ascorbic acid contents were associated with the highest content of the nutrient elements in the leaves (tables 2 and 4).

\section{Weight of fruits and roots}

Table 5 shows the effects of the major elements on weight of fruits and roots. Increments of nitrogen, phosphorus, and potassium were responsible 
for significant reductions in fruit weight along with production of a greater number of fruits. This brought out significant differences in yield, as was previously shown in table 2.

TABLE 7.-Influence of minor-element fertilizers, lime, and other soil amentments on. the ascorbic acid content of acerola fruits grown on

Sabana. Seca sandy clay, crop of 1955

\begin{tabular}{|c|c|c|c|c|c|c|c|c|c|}
\hline \multirow{3}{*}{$\begin{array}{l}\text { Treat- } \\
\text { ment } \\
\text { No. }\end{array}$} & \multicolumn{3}{|c|}{$\begin{array}{l}\text { Major elements } \\
\text { used per acre }\end{array}$} & \multirow{3}{*}{ Minor element or soil amendment } & \multirow{3}{*}{$\begin{array}{c}\text { Rate per } \\
\text { acre }^{2}\end{array}$} & \multicolumn{4}{|c|}{$\begin{array}{l}\text { Ascorbic acid of whole } \\
\text { fruit per } 100 \mathrm{gm} .\end{array}$} \\
\hline & \multirow{2}{*}{$\mathrm{N}$} & \multirow{2}{*}{$\mathrm{P}_{2} \mathrm{O}_{8}$} & \multirow{2}{*}{$\mathrm{K}=\mathrm{O}$} & & & \multicolumn{3}{|c|}{ Pickings } & \multirow{2}{*}{$\begin{array}{l}\text { Average } \\
\text { for } 3 \\
\text { pickings }\end{array}$} \\
\hline & & & & & & First & Second & Third & \\
\hline & Lb. & $\boldsymbol{L} \boldsymbol{b}$. & $\boldsymbol{L b}$. & & Lb. & 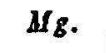 & $\mathbf{d}_{\boldsymbol{g}}$. & $M g$. & Mg. \\
\hline 7 & 200 & 200 & 200 & Lime only & & 2,042 & 2,170 & 1,315 & 1,842 \\
\hline 8 & 200 & 200 & 200 & Hyper-Humus & 20,000 & 1,331 & 1,421 & 1,022 & 1,258 \\
\hline 9 & 200 & 200 & 200 & $\begin{array}{l}\text { F.T.E. (fritted trace ele- } \\
\text { ments) }\end{array}$ & 200 & 1,090 & 1,735 & 1,188 & 1,338 \\
\hline 10 & 200 & 200 & 200 & EDTA Fe (chelated iron) & 100 & 1,340 & 1,445 & 1,031 & 1,272 \\
\hline 11 & 200 & 200 & 200 & $\begin{array}{l}\text { ES-MIN-EL (minor-ele- } \\
\text { ment mixture) }\end{array}$ & 100 & 1,494 & 1,885 & 1,034 & 1,471 \\
\hline 12 & 200 & 200 & 200 & do. & $4^{3}$ & 1,370 & 1,358 & 1,166 & 1,298 \\
\hline 13 & 200 & 200 & 200 & $\begin{array}{l}\text { Nutri-Leaf (soluble minor } \\
\text { elements) }\end{array}$ & $6^{3}$ & 1,494 & 1,993 & 1,025 & 1,504 \\
\hline 14 & 100 & 100 & 100 & Filter-press cake & 40,000 & 1,438 & 1,778 & 1,157 & 1,458 \\
\hline 15 & 200 & 200 & 200 & $\begin{array}{l}\text { Mineral-Mixture (minor- } \\
\text { element mixture) }\end{array}$ & 100 & 1,326 & 1,598 & 1,414 & 1,446 \\
\hline 16 & 200 & 200 & 200 & Unlimed (pH 4.5) & - & 1,320 & 1,660 & 1,085 & 1,355 \\
\hline c. & & 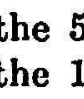 & & 280 & & $\begin{array}{l}321 \\
433\end{array}$ & $\begin{array}{l}448 \\
605\end{array}$ & $\begin{array}{l}406 \\
547\end{array}$ & $\begin{array}{l}247 \\
333\end{array}$ \\
\hline
\end{tabular}

${ }^{1}$ All treatments except no. 16 received $4,000 \mathrm{lb}$. of lime to raise soil $\mathrm{pH}$ to 6.5 .

2 Materials mixed with the soil.

3 Materials mixed with 100 gal. of water and sprayed on trees.

The application of the first 100 pounds of each major element did not significantly affect additional root development of the acerola; however, the use of an additional 100 pounds of each fertilizer element did increase root volume significantly. It is of interest to note that lime definitely proved of value in root development (compare treatment 7 with treatment 8 , table 5). Under liming a 70-percent increase in root weight was obtained in trees which received the top rate of the major elements as compared with those in unlimed soil, but which also were supplied with maximum nitrogen, phosphorus, and potassium. 
MINOR ELEMENTS, LIME, AND OTHER SOIL AMENDMENTS

The effect of minor-element mixtures, lime, Hyper-Humus, and filter-press cake, on acerola yields and ascorbic acid content of the fruit are given in tables 6 and 7. None of the minor-element fertilizers or soil amendments,

TABLE 8.-Mean weight of acerola fruits as influenced by minor-element fertilizers, lime, and other soil amendments, when grown on Sabana Seca sandy clay, 1955-56

\begin{tabular}{|c|c|c|c|c|c|c|c|c|}
\hline \multirow{2}{*}{$\begin{array}{c}\text { Treat- } \\
\text { ment } \\
\text { No. }\end{array}$} & \multicolumn{3}{|c|}{$\begin{array}{l}\text { Major elements } \\
\text { used per acre }\end{array}$} & \multirow{2}{*}{ Minor element or soil amendment } & \multirow{2}{*}{$\begin{array}{l}\text { Rate of } \\
\text { application } \\
\text { per acre }\end{array}$} & \multicolumn{2}{|c|}{$\begin{array}{l}\text { Mean weight } \\
\text { of fruits }\end{array}$} & \multirow{2}{*}{$\mid \begin{array}{c}\text { Mean } \\
\text { weight } \\
\text { of fruit: }\end{array}$} \\
\hline & $\mathbf{N}$ & $\mathbf{P}_{2} \mathrm{O}_{6}$ & $\mathrm{~K}_{2} \mathrm{O}$ & & & 1955 & 1956 & \\
\hline & $L b$. & $L b$. & $\boldsymbol{L b}$. & & & Gm. & $G m$. & $\mathrm{Gm}$. \\
\hline 7 & 200 & 200 & 200 & Lime only & & 4.419 & 6.044 & 5.232 \\
\hline 8 & 200 & 200 & 200 & Hyper-Humus & 20,000 & 5.746 & 7.677 & 6.712 \\
\hline 9 & 200 & 200 & 200 & $\begin{array}{l}\text { F.T.E. (Fritted trace ele- } \\
\text { ments) }\end{array}$ & 200 & 5.525 & 6.133 & 5.829 \\
\hline 10 & 200 & 200 & 200 & EDTA Fe (chelated iron) & 100 & 6.042 & 7.092 & 6.567 \\
\hline 11 & 200 & 200 & 200 & $\begin{array}{l}\text { ES-MIN-EL (minor-element } \\
\text { mixture) }\end{array}$ & 100 & 6.034 & 6.636 & 6.335 \\
\hline 12 & 200 & 200 & 200 & do. & $4^{3}$ & 6.468 & 7.159 & 6.814 \\
\hline 13 & 200 & 200 & 200 & $\begin{array}{l}\text { Nutri-Leaf (soluble minor } \\
\text { elements) }\end{array}$ & $6^{3}$ & 4.805 & 6.321 & 5.563 \\
\hline 14 & 100 & 100 & 100 & Filter-press cake & 40,000 & 5.452 & 6.840 & 6.146 \\
\hline 15 & 200 & 200 & 200 & $\begin{array}{l}\text { Mineral-Mixture (minor- } \\
\text { element mixture) }\end{array}$ & 100 & 4.390 & 7.436 & 5.913 \\
\hline 16 & 200 & 200 & 200 & Unlimed (pH 4.5) & 一 & 5.806 & 5.619 & 5.713 \\
\hline .8 & & & & & & $\begin{array}{r}0.453 \\
.611\end{array}$ & $\begin{array}{l}0.927 \\
1.249\end{array}$ & 1.272 \\
\hline
\end{tabular}

${ }^{1}$ All treatments except treatment number 16 received $4,000 \mathrm{lb}$. of lime to raise soil to $\mathrm{pH} 6.5$.

${ }^{2}$ Material mixed with the soil.

${ }^{3}$ Material mixed with water and sprayed on tree at the rate of 100 gal. per acre.

aside from lime, gave any significant increase in yield of acerolas (table 6). For the average of three pickings the ascorbic acid content of the fruit significantly decreased when the minor-element mixtures or soil amendments were used (table 7). Lime definitely proved of value in acerola production, both increasing the yield of fruits and their ascorbic acid content. For the average of three crops (table 6) the increase in fruit yield from the use of lime was 12.46 hundredweights, which was 102 percent higher than for the no-lime treatment 16. Lime appeared also to be responsible for an increase in the ascorbic acid of the fruit which amounted to $487 \mathrm{mg}$. per 
$100 \mathrm{gm}$. of whole fruit. (Compare treatment 7 with treatment 16, table 6.) This increase is equivalent to 36 percent more ascorbic acid.

\section{Weight of fruits}

The influence of minor-element fertilizers, lime, and other soil amendments on fruit weight is given in table 8. In general, the use of lime alone significantly reduced fruit size in the crop of 1955 , but more fruits were produced; this was responsible for significant yield differences. In the crop of 1956 lime was still responsible for smaller fruit size but significantly in some cases only.

\section{DISCUSSION}

The investigation reported in this paper clearly underlines the outstanding beneficial effects of nitrogen, phosphorus, potassium, and lime on yield of acerolas and on the ascorbic acid content of the fruit, when grown in an acid ( $\mathrm{pH}$ 4.5) light-textured soil (Sabana Seca sandy clay) that is being used at present on relatively large scale for acerola production.

It was found that lime was an important factor affecting root growth and development. It aided significantly in increasing the root volume of trees, giving them a larger feeding area as a result, and probably also increasing their ability to absorb nutrients more efficiently for their metabolic processes. Trees supplied with lime had a thrifty growth with dark-green foliage. On the other hand, visual symptoms of calcium deficiency were noted in the unlimed acerola trees which were similar to those observed in trees grown under field conditions in the same soil used in this test, as well as to those developed on calcium-deficient trees growing in sand culture under controlled conditions ( 7 ). The observations noted above suggest that lime was beneficial to acerola because of the nutrient calcium it provided. The essentiality of calcium for root growth and plant development has been well demonstrated by several investigators $(8,9,16)$. The beneficial effect that lime might have had in this experiment by correcting soil acidity is also something worth considering in future research work.

Lime by itself was such a limiting factor that not even the efficient use of the major-element fertilizers was achieved without it. For example, it was found that 100 pounds of nitrogen per acre combined with lime gave mean yields of 25 hundredweights of fruits per acre, whereas with 200 pounds of nitrogen per acre and no lime only 20.9 hundredweights were obtained. Thus, even with half the nitrogen, a greater yield was obtained when lime was used. Similar trends were observed with phosphorus and potassium and lime. 
The data presented in this paper suggest that the use of lime in combination with high rates of the major elements is of paramount importance, for obtaining high yields of both acerola fruits and ascorbic acid on a Sabana Seca sandy clay soil.

\section{SUMMARY}

The influence of major and minor elements, lime, and other soil amendments on the yield and ascorbic acid content of acerolas growing on a Sabana Seca sandy clay soil ( $\mathrm{pH} \mathrm{4.5)}$ was investigated and the results obtained may be summarized as follows:

1. Significant yield responses were associated with increasing rates of nitrogen, phosphorus, and potassium in the substrate.

2. The maximum rates of nitrogen, phosphorus, and potassium, 200 pounds per acre, significantly increased the ascorbic acid content of the fruit.

3. For the average of three crops the omission of nitrogen from the fertilizer mixture gave the greatest reduction in yield; this was followed by results from lack of potassium and phosphorus, in the order mentioned.

4. Maximum fruit yields and ascorbic acid contents were associated with the highest nutrient levels of nitrogen, phosphorus, and potassium in the leaves.

5. Increasing quantities of the major elements in the substrate signifcantly reduced fruit weight at the apparent expense of more fruits produced; this was responsible for significant yield differences.

6. The maximum rate of N-P-K used increased root development significantly. Lime definitely benefitted root development. Top-root weights were obtained on limed plots with highest levels of nitrogen, phosphorus, and potassium.

7. None of the minor-element fertilizers or soil amendments, aside from lime, produced any significant increase in yield of fruits. Ascorbic acid was significantly decreased when the minor-element mixtures or soil amendments were used.

8. Lime definitely proved to be beneficial for acerola production, both in yield of fruits and ascorbic acid. Trees in limed soil were thrifty with darkgreen foliage as compared to the poor growth made by trees in unlimed soil. These trees also appeared to be calcium-deficient.

\section{RESUMEN}

Este trabajo informa los datos obtenidos de un experimento llevado a cabo por tres años consecutivos sobre el efecto de la aplicación de elementos 
nutritivos, tanto mayores como menores, cal y otras enmiendas al suelo, sobre los rendimientos de árboles de acerolas y sobre el contenido de ácido ascórbico de la fruta.

Los resultados obtenidos de este estudio pueden resumirse como sigue:

1. Los aumentos de nitrógeno, fósforo y potasio en el suelo aumentaron significativamente la producción de frutas.

2. La cantidad máxima de nitrógeno, fósforo y potasio que se usó, o sea, 200 libras por acre, aumentó significativamente el contenido de ácido ascórbico de la fruta.

3. Cuando no se usó nitrógeno en el abono hubo la mayor reducción en los rendimientos de frutas. Bajaron también los rendimientos con la falta de potasio y fósforo en el abono en el orden indicado.

4. La producción máxima de frutas y ácido ascórbico estuvo asociado al contenido máximo de nitrógeno, fósforo y potasio en las hojas del árbol.

5. Los aumentos de nitrógeno, fósforo y potasio redujeron el peso de la fruta, pero hubo un mayor número de frutas por árbol. Esto causó diferencias significativas al comparar los rendimientos.

6. La aplicación de los elementos nutritivos mayores en su cantidad máxima conjuntamente con cal favoreció grandemente la producción de raíces. Se obtuvo el mayor peso de raíces en las parcelas encaladas que contenían las cantidades máximas de nitrógeno, fósforo y potasio.

7. Ninguna de las mezclas de elementos menores o enmiendas al suelo, fuera de la cal, pudo aumentar significativamente la producción de frutas. El ácido ascórbico disminuyó significativamente cuando se usaron las mezclas de elementos menores o enmiendas al suelo.

8. Las aplicaciones de cal fueron muy beneficiosas en cuanto a la producción de frutas y ácido ascórbico. Los árboles en el suelo encalado se desarrollaron con vigor y adquirieron un follaje denso y de color verde oscuro. Los árboles en el suelo sin encalar tuvieron un desarrollo pobre y demostraron los síntomas típicos de deficiencia en calcio.

\section{LITERATURE CITED}

1. Aróstegui, F., and Pennock W., The Acerola, Misc. Pub. 15, Agr. Exp. Sta. Univ. P.R., Río Piedras, P.R., April 1955.

2. Asenjo, C. F., and Freire de Guzmán, A. R., The high ascorbic acid content of the West Indian cherry, Sci., 103 219, 1946.

3. Association of Official Agricultural Chemists, Official and Tentative Methods of Analysis, 8th ed., 11, 1955.

4. Ballentine, R., Determination of ascorbic acid in citrus fruit juices, Ind. Eng. Chem. Anal. Ed. 13 (2) 89, 1941.

5. Capo, B. G., A modification of Mitscherlich's method for the determination of the nutrient contents of a soil, J. Agr. Univ. P.R. 22 (2) 137-69, 1938.

6. Capó, B. G., Samuels, G., Landrau, P. Jr., Alers-Alers, S., and Riera, A., The 
Method of Foliar Diagnosis as Applied to Sugarcane, Bull. 123, Agr. Exp. Sta. Univ. of P.R. 1-47, 1955.

7. Cibes-Viadé, H. R., and Samuels, G., Mineral-Deficiency Symptoms Displayed by Acerola Trees Grown in the Greenhouse under Controlled Conditions, Tech. Paper 15, Agr. Exp. Sta., Univ. P.R., Río Piedras, P.R., 1955.

8. Haynes, J. L., and Robbins, W. Rei, Calcium and boron as essential factors in the root environment, $J$. Amer. Soc., Agron 40 (9) 795-803, 1948.

9. Hernández Medina, E., and Shive, J. W., Calcium-boron relationships in the nutrition of corn and the distribution of these elements in the plant, $J$. Agr. Univ. P.R. 30 (4) 251-91, 1946.

10. Moscoso, C. G., West Indian cherry-richest known source of natural vitamin C, Econ. Bot. 10 (3) 280-94, 1956.

11. Munsell, H. E., Ascorbic Acid content of fruits of Puerto Rico with data on miscellaneous products, Food Res. 10 (1) 42-51, 1945.

12. Mustard, M. J., The ascorbic acid content of some Malpighia fruits and jellies, Sci. 104 230-1, 1946.

13. Quiñones, V. L., Guerrant, N. B., and Dutcher, R. A., Vitamin content of some tropical fruits, their juices and nectars, Food Res. 9 (5) 415, 1944.

14. Riera, A., Laboratory recommendations of lime to an acid soils checks with expected pH changes, J. Agr. Univ. P.R. 30 (3) 184-5, 1946.

15. Roberts, R. C., Soil Survey of Puerto Rico, U.S.D.A., Bur. Plant Ind. in cooperation with the Univ. of P.R., Agr. Exp. Sta., Series 1936 (8) 1942.

16. True, R. H., The significance of calcium for higher green plants, Sci. 65 1-6, 1922. 